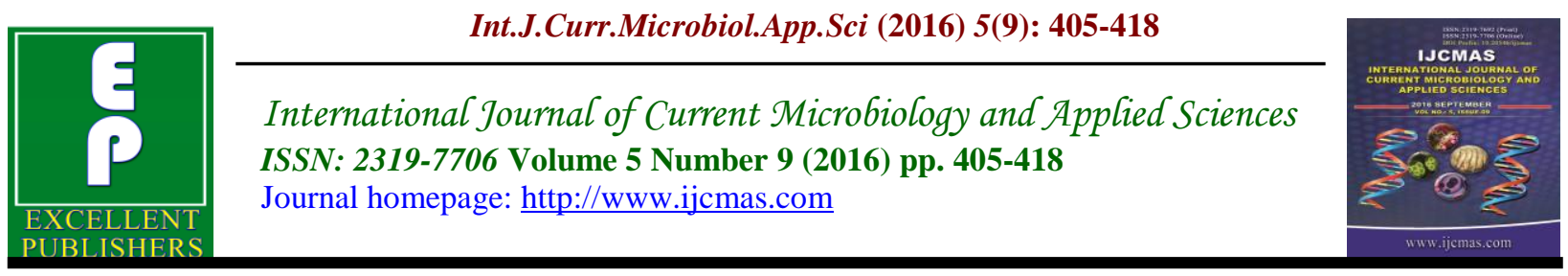

Original Research Article

http://dx.doi.org/10.20546/ijcmas.2016.509.044

\title{
A Comparative Microbial Quality Assessment among Fishes, Prawns and Cuttlefishes collected from Dammam Fish Market
}

\author{
Sami Shabeeb Al Shabeeb, M.A. Mohamed Ibrahim* and Ghamri H. Al Ramadhan \\ Fisheries Research Center, Deputy Ministry for Fisheries, Ministry of Environment, \\ Water \& Agriculture, Kingdom of Saudi Arabia \\ *Corresponding author
}

\begin{abstract}
A B S T R A C T
Keywords

Microbial Quality,

Pathogenic

bacteria, Isolation, API, Quality assurance.

\section{Article Info}

Accepted:

15 August 2016

Available Online:

10 September 2016

A study was conducted to evaluate the microbial quality of seafoods collected from Dammam fish market, Saudi Arabia. In this study, Fishes, Prawns and Cuttlefishes (10 samples each) were analysed in 6 sample categories such as Fish skin, Fish gills, Fish muscles, Prawn, Cuttlefish skin and Cuttlefish muscles. Bacterial isolates were characterized on specific culture mediaand further confirmed using API 20E, API 20NE, API ID32 Staph strips and identified by "api web". Total Plate Count of bacteria and Total Coliforms Count were conducted only for muscles samples and the occurrence of specific pathogenic bacteria was determined for all samples. In such investigation, the TPC values of Prawns exceed the marginal level of acceptability and the Total Coliform Counts were exceeding the limits in all the samples analysed. And species of different bacterial isolates were identified such as, Aeromonas spp, Staphylococci spp, Vibrio spp, Enterobacteriaceae, Shewanella putrifaciens, Pasteurella aerogenes, Aerococcus viridans, Ralstonia pickettii, Acinetobacter baumannii and Psuedomonas luteola. The results of this study indicate the urgent need required to improve the Quality Control and Quality Assurance systems of Dammam Fish Market.
\end{abstract}

\section{Introduction}

Fish and fishery products are one of the major food constituents from ancient time (Noor et al., 2013) Fish can be Finfish, Shellfish (molluscs and crustaceans), or any other form of marine or freshwater animal life that can be used for human or domestic animal consumption (Mahumda et al., 2010). Fish is a major source of protein and its harvesting, handling, processing and distribution provide livelihood for millions of people (Al-sufaili and Opara, 2006).
Fish because of their soft tissues and aquatic environment are immensely prone to microbial contamination. Most of the bacterial population which are present in the surface slime, on the gills and the intestines of live fish are potential spoilers, but the flesh itself is normally sterile. The immune system of healthy fish will prevent the invasion and multiplication of bacteria when it is alive. But after death the immune system collapses and the bacteria invade and proliferate in the flesh. And also 
immediately fish dies, it remains in first class quality only for a short period of time (Clucas and Ward, 1996).

Food security is a complex issue, where fish and fishery products are generally regarded as high risk commodity in respect of its pathogen contents, natural toxins and other possible contaminants and adulterants (Kawser et al., 2008). The microbial populations which are mainly present in the outer surfaces (skin and gills) are responsible for the spoilage of newly caught fresh fishes. But it can also be the result of cross-contamination due to the inappropriate handling and storage of fishes (CruzRomero et al., 2008).

Spoilage of fresh fishes is due to the microbiological activity, Chemical oxidation of lipids and autolysis. The primary cause of the organoleptic rejection of fresh fish is due to the growth of bacteria which utilize the nutrients and produce by-products that results in the accumulation of metabolic products in the fish. Fraction of the initial microbial population present in the fishes known as Specific Spoilage Organisms (SSO) causes the spoilage by producing metabolites which are responsible for offflavors and cause the organoleptic rejection of the product. Such conditions are determined mostly by the temperature and atmospheric conditions during storage (Gram and Huss, 1996).

The specific type of bacteria which are responsible for the spoilage activity of fish muscles after death is mainly depends on the type of fish and its chemical composition, the feeding habit, the area where the fish is harvested and the type of fishing gear used during harvesting (Francoise, 2010; Huis in't veld, 1996). The indigenous microbial populations of freshly caught fish can vary significantly based on the environment in which the fish are caught and not of the fish species (Shewan, 2000).

These types of fishes may also infect the people who are associated with handling during transportation of such fishes to the landing centers and wholesale markets. When the consumers purchase these fishes, the associate microorganisms are transferred to the persons who carry those (Das et al., 2007). Regarding to the potential public health threat that the seafood may constitute, the main purpose of this study was to determine and evaluate the microbial contamination of seafood products collected from retailfish market at Dammam.

\section{Materials and Methods}

\section{Sample collection}

30 seafood samples comprising of Fishes, Prawns and Cuttle fishes (10 samples each) were collected from the retail shops in Dammam fish market. In this study five species of fishes were selected for the analysis of microbial loads along with common cuttlefish and Prawns. They are, Spangled Emperor (Lethrinus nebulosus), Long spined Bream (Acanthopagrus berda), Golden Trevally (Gnathanodonspeciosus), Two bar Bream (Acanthopagrus bifasciatus), Common cuttlefish (Sepia officinalis), Indian white prawn (Penaeus indicus). Samples were collected and kept in sterile polyethylene bags embedded with ice and transported rapidly to the laboratory in an insulated box. The time gap between the collection of samples and analysis was approximately 1 hour.

\section{Preparation of samples}

\section{Skin surface}

Samples of the skin of fishes and cuttlefishes were taken by rubbing the 
sterilized cotton swab over the skin and then inoculating in to the nutrient broth, incubated at $37^{\circ} \mathrm{C}$ for 24 hours and further analyzed for the presence of specific bacteria.

\section{Gills}

A part of the gill filament of fish was exposed with the aid of a pair of forceps was swabbed with a sterile cotton swab and inoculated in to the nutrient broth, incubated at $37^{\circ} \mathrm{C}$ for 24 hours and further analyzed for the presence of specific bacteria.

\section{Muscles}

This was done by cutting $50 \mathrm{~g}$ of muscle with sterile scalpel and is mixed in $450 \mathrm{ml}$ of sterile physiological saline in a filter stomacher bag and made in to slurry using the BagMixer® (Interscience, France). The resulting solution represent a dilution stage of $10^{-1}, 10^{-2}, 10^{-3}$ and $10^{-4}$ were prepared by transferring $10 \mathrm{ml}$ of the previous dilution in to $90 \mathrm{ml}$ of sterile physiological saline and so on. Mixing of the sample at each dilution was also done by rotating and shaking vigorously, so as to resuspend the material uniformly.

\section{Isolation and Identification of pathogens of public health significance}

All media used in the present study were from Oxoid, U.K. and prepared according to the standard procedure. Media were sterilized by autoclaving at $121^{\circ} \mathrm{C}$ at $15 \mathrm{psi}$ pressure for 15 minutes, unless otherwise specified. Sterility of the media was checked by incubating at $37^{\circ} \mathrm{C}$ for 24 hours.

In this present study, the Total Plate Count (TPC) of bacteria and Total Coliforms Count (TCC) were conducted only for muscle samples of the Fishes, Prawns and
Cuttlefishes (10 samples each) and the occurrence of pathogens of public health significance were determined for samples in 6 categoriessuch as Fish skin, Fish gills, Fish muscles, Prawn, Cuttlefish skin and Cuttlefish muscles (10 samples each).

The microbiological analysis was performed as per the standard methods adopted from Online Bacteriological Analytical Manual, USFDA, for detection, enumeration and identification of individual organisms (BAM $8^{\text {th }}$ edition Online).

\section{Total Plate Count (TPC)}

$50 \mathrm{~g}$ of the sample were homogenized in 450 $\mathrm{ml}$ of sterile physiological saline. After serial dilution up to fourth dilution, the samples were pour-plated on Plate Count Agar (PCA). The colonies were counted after 48 hours of incubation of the plates at $37^{\circ} \mathrm{C}$.

\section{Total Coliform Count (TCC)}

Dilutions made for the Total Plate Count were plated on Violet Red Bile Agar (VRBA); typical Purple colonies surrounded by a purple zone were counted after 24 hours of incubation of the plates at $37^{\circ} \mathrm{C}$.

\section{Enterobacteriaceae}

Dilutions made for the Total Plate Count were plated on MacConkey Agar. After 24 hours of incubation at $37^{\circ} \mathrm{C}$, both Pink and Colourless colonies were picked up, purified and identified further by subsequent biochemical tests using API 20E strips (Biomerieux, France), and the identification was obtained by using the "api web".

\section{Aeromonas species}

Dilutions made for the Total Plate Count were plated on Aeromonasmedium. After 24 
hours of incubation at $37^{\circ} \mathrm{C}$, both atypical and typical colonies were picked up, purified and identified further by subsequent biochemical tests using API 20NE strips (Biomerieux, France), and the identification was obtained by using the "api web".

\section{Staphylococcus species}

Dilutions made for the Total Plate Count were plated on Baird Parker Agar (BPA) and Mannitol Salt Agar (MSA). After 24 48 hours of incubation at $37^{\circ} \mathrm{C}$, bothatypical and typical colonies were picked up, purified and identified further by subsequent biochemical tests using API ID32 Staph strips (Biomerieux, France), and the identification was obtained by using the "api web".

\section{Salmonella species}

$25 \mathrm{~g}$ of the sample was homogenized in 225 $\mathrm{ml}$ of Lactose Broth (LB) and incubated overnight at $37^{\circ} \mathrm{C}$. After the initial preenrichment step, samples were selective enriched in Tetrathionate Broth (TTB) at $37^{\circ} \mathrm{C}$ and Rappaport Vassiliadis (RV) medium at $42^{\circ} \mathrm{C}$ and incubated overnight. A loopful of growth from each of these media was streaked on Bismuth Sulphite Agar (BSA), Xylose Lysine Desoxycholate Agar (XLDA) and Hektoen Enteric Agar (HEA). After 24 (HEA, XLD) - 48 (BSA) hours of incubation at $37^{\circ} \mathrm{C}$, both atypical and typical colonies were picked up, purified and identified further by subsequent biochemical tests using API 20E strips (Biomerieux, France), and the identification was obtained by using the "api web".

\section{Vibrio species}

$25 \mathrm{~g}$ of the sample were homogenized in 225 $\mathrm{ml}$ of Alkaline Peptone Water (APW) and incubated overnight at $37^{\circ} \mathrm{C}$. After secondary enrichment for six hours in APW, a loopful of the culture from primary and secondary enrichment media was streaked on Thiosulphate Citrate Bilesalt Sucrose Agar (TCBS). After 24 hours of incubation at $37^{\circ} \mathrm{C}$, both atypical and typical colonies were picked up, purified and identified further by subsequent biochemical tests using API 20NE strips (Biomerieux, France), and the identification was obtained by using the "api web".

\section{Statistical Analysis}

The results of the present study were tabulated and statistical analyses were conducted using the software: Statistical Package of the Social Sciences (SPSS) version 22 .

\section{Results and Discussion}

The results of the range of Total Plate Count (TPC) of bacteria on the Plate Count Agar and Total Coliforms Count on the Violet Red Bile Agar are shown in Table 1 and Table 2 respectively. Mean Total Plate Count of the three different types of samples are presented in Table 3. The highest number of bacterial count was obtained from prawn which was $6.15 \pm 1.22 \times 10^{6} \mathrm{CFU} / \mathrm{g}$, followed by Cuttlefish with the count of $3.23 \pm 5.50 \times 10^{5} \mathrm{CFU} / \mathrm{g}$ while least count of $2.95 \pm 2.37 \times 10^{5} \mathrm{CFU} / \mathrm{g}$ was obtained from Fishes. Also, Table 3 showed the result obtained for the mean Total Coliform Count ranged from $8.04 \pm 1.01 \times 10^{3} \mathrm{CFU} / \mathrm{g}, 7.31$ $\pm 3.98 \times 10^{3} \mathrm{CFU} / \mathrm{g}, 4.13 \pm 5.19 \times 10^{3}$ CFU/g for Cuttlefishes, Fishes and Prawns respectively.

Results of cultural and morphological characteristics showed that most isolates were gram negative rods. Two gram positive cocci were isolated. The bacterial isolates from the six categories of samples (Fish 
skin, Fish gills, Fish muscles, Prawn, Cuttlefish skin and Cuttlefish muscles) included Vibrio spp, Aeromonas spp, Enterobacteriaceae, Pasteurella spp, Shewanella spp, Staphylococcus spp, Aerococcus spp, Ralstonia spp, Acinetobacter spp and Psuedomonas spp are shown in Table 4 and Table 5. The overall percentages of prevalent bacterial families were shown in Table 6.

In this study three types of seafoods including Fishes, Prawns and Cuttlefishes were anaylsed in six sample categories (Fish skin, Fish gills, Fish muscles, Prawn, Cuttlefish skin and Cuttlefish muscles) for the presence of microorganisms; the mean Total Plate Count (TPC) of bacteria gave the following $2.95 \pm 2.37 \times 10^{5} \mathrm{CFU} / \mathrm{g}, 6.15 \pm$ $1.22 \times 10^{6} \mathrm{CFU} / \mathrm{g}$ and $3.23 \pm 5.50 \times 10^{5}$ $\mathrm{CFU} / \mathrm{g}$ for Fishes, Prawns and Cuttlefishes respectively. According to SASO, the TPC values are within the permissible range for Fishes and Cuttlefishes. SASO specifies the upper (Rejectable) and lower (Marginal) levels of acceptability as $1.0 \times 10^{7}$ and $5.0 \mathrm{x}$ $10^{5} \mathrm{CFU} / \mathrm{g}$ respectively. According to the TPC value, the Prawns which have the count of $6.15 \pm 1.22 \times 10^{6} \mathrm{CFU} / \mathrm{g}$ exceeds the marginal levels of acceptability and were not fit for human consumption.

The mean Total Coliforms Count gave the following, $7.31 \pm 3.98 \times 10^{3} \mathrm{CFU} / \mathrm{g}, 4.13 \pm$ $5.19 \times 10^{3} \mathrm{CFU} / \mathrm{g}$ and $8.04 \pm 1.01 \times 10^{3}$ CFU/g for Fishes, Prawns and Cuttlefishes respectively. Nearly similar results were obtained in Algeria by Amira et al, (2014). According to ICMSF, Total Coliforms limits, $1.0 \times 10^{2} \mathrm{CFU} / \mathrm{g}$ can be present in the food. But all of the Fishes, Prawns and Cuttlefishes samples analysed were exceeding the limit. This unacceptable counts of Coliforms might be the result of possible contamination during sales or unhygienic handling of seafood that could be contaminated water used for processing
(Okonko et al., 2008) or Ice used for to freeze (Intesar, 2003.)

Out of 60 samples analysed, 40 (66.66\%) samples were found to be contaminated with Aeromonas sp., with the prevalence of Aeromonas hydrophila (31), Aeromonas sobria (8) and Aeromonas salmonicida (1) respectively. The ranges of incidence levels of Aeromonads were from Cuttlefish muscles (12), Fish Gills (8), Fish muscles (7), Fish skin (6), Cuttlefish Skin (4) and Prawn (3). The level of incidence was higher when compared to the observations of Tsai and Chen (1996), Fricker and Tompsett (1989), Hudson and Delacy (1991) and Vivekanandhan (1991) from different geographical regions. Some of the species of motile Aeromonads became emerging pathogens due to their ability to produce virulence factors, not only at optimum temperature but also under cold storage conditions (Neyts et al., 2000). Aeromonas spp. are normal inhabitants of the aquatic medium. Due to the incidence of human disease caused by Aeromonas after consumption of the contaminated foods, it was considered as a human pathogen. Their ability to produce extracellular haemolysin, enterotoxins, cytotoxins, lipases and proteases are responsible for the spoilage of foods and pathogenicity (Farag, 2006).

Salmonella was not detected in the samples analysed in this study, which was in agreement with previous studies (Popovic et al., 2010; Rodriquez et al., 2011; Figen et al., 2014) in seafood products. Conversely, different workers (Shabrinath et al., 2007; Kumar et al., 2009; Bakr et al., 2011) reported varying incidence rates of Salmonella in seafood.

From the results of this study, it can be seen that the seafoods sold in Dammam market has high contamination of enteric organisms like Escherichia coli, Morganella morganii, 
Proteus sp, Enterobacter sp, Citrobacter sp, Klebsiella pneumoniae, Providencia stuartii, Hafnia alvei and Rahnella aquatilis. Out of 60 samples analysed, Enterobacteriaceae comprises of about $31(51.66 \%)$ isolates. In a study of Yagoub (2009), Enterobacteriaceae were isolated from Gills, Skin, Muscles and Intestine of 83 out of $150(55 \%)$ randomly collected fishes, the most dominant isolates were Escherichia coli, Citrobacter sp, Enterobacter sp and Klebsiella sp.The Enterobacteriaceae are all occurring on fish products as a result of contamination from the animal/human reservoir. This contamination has normally been associated with faecal contamination or pollution of natural waters or water environments, where these organisms may survive for a long time (months) or through direct contamination of products during processing (FAO).

Among the 148 isolates, it was observed that 35 isolates were Gram positive bacteria. Out of this the most predominant were Staphylococcus sp (30) and Aerococcus viridans (5). Among the recovered Staphylococci, the most predominant species were Staphylococcus hominis (7) which was isolated from Fish muscles (2), Prawns (2) and Cuttlefish muscles (3). And Staphylococcus lentus (7) from Fish skin (3), Gills (1) and Cuttlefish skin (3). Followed by Staphylococcus aureus (5) from Cuttlefish Skin (2) and Cuttlefish muscles (3). Nearly similar results were obtained by Evelyn et al., (2015).

Staphylococci are not part of the normal fish microbiota (Huss, 1988; Van den Broek et $a l, 1984)$. They are frequently found in the nose, respiratory tract, skin of the human scalp, face, neck, ears, axillae, perineum and the pubic region. They can cause food poisoning and may occasionally cause infections in patients whose immune system is compromised (Karl, 1975; Wesley, 1975).
Hence, the presence of Staphylococci in seafood samples indicates the post-harvest contamination due to poor personnel hygiene or due to the disease in fish (Austin and Austin, 2007; Huss, 1988). Aerococcus viridans can be found in the marine environments that can cause fatal disease in lobster and can also act as an opportunistic pathogen in immune compromised patients (Young Uh et al., 2002). The presence of such microorganisms in fish which are not the part of microbiota of these aquatic organisms indicates the occurrence of food contamination due to poor hygiene in handling and lack of preservation techniques (Evelyn et al., 2015).

The present study revealed that the microbial quality of seafood samples from Dammam fish market was not good due to the presence of Vibrio in most samples. Presence of Vibrio sp, can be a cause of infection to the consumers. In the present investigation, Vibrio sp, was studied qualitatively and found in Fish gills, Fish muscles, Prawns and Cuttlefish muscles. It was absent in Fish skin and Cuttlefish skin. Totally 28 isolates were recovered and predominant Vibrio sp, from all positive samples include, Vibrio parahaemolyticus (12), followed by Vibrio alginolyticus (10), Vibrio vulnificus (3), Vibrio cholerae (2) and Vibrio fluvialis (1). El Hadiet al., detected the presence of potentially pathogenic Vibrio species, with overall incidence in the samples as $4.7 \%$ for Vibrio parahaemolyticus, $11 \%$ for Vibrio alginolyticus, $6 \%$ for Vibrio vulnificus, $4.6 \%$ for Vibrio cholerae and $7.6 \%$ for Vibrio fluvialis. Okonko et al., isolated 53 Vibrio species in seafoods with the predominance of Vibrio cholerae (47.2\%), Vibrio parahaemolyticus (18.9\%), Vibrio mimicus (15.1\%), Vibrio fluvialis (13.2\%), Vibrio alginolyticus (3.8\%) and Vibrio vulnificus (1.9\%). 
Table.1 Range of Total Plate Count (TPC) cfu/g in the examined samples of Fishes, Prawns and Cuttlefishes

\begin{tabular}{|l|c|c|c|c|}
\hline Sample Type & $\begin{array}{c}\text { Number of } \\
\text { samples with } \\
\text { count } \mathbf{>} \mathbf{1 0}^{\mathbf{4}}\end{array}$ & $\begin{array}{c}\text { Number of } \\
\text { samples with } \\
\text { count }>\mathbf{1 0}^{\mathbf{5}}\end{array}$ & $\begin{array}{c}\text { Number of } \\
\text { samples with } \\
\text { count }>\mathbf{1 0}^{\mathbf{6}}\end{array}$ & $\begin{array}{c}\text { Number of } \\
\text { samples with } \\
\text { count }>\mathbf{1 0}^{\mathbf{7}}\end{array}$ \\
\hline Fish & 3 & 7 & --- & -- \\
\hline Prawn & 3 & 3 & 2 & 2 \\
\hline Cuttlefish & 3 & 6 & 1 & -- \\
\hline
\end{tabular}

Table.2 Range of Total Coliforms Count (TCC) cfu/g in the examined samples of Fishes, Prawns and Cuttlefishes

\begin{tabular}{|l|c|c|c|c|}
\hline Sample Type & $\begin{array}{c}\text { Number of } \\
\text { samples with } \\
\text { count }<\mathbf{1 0}^{\mathbf{2}}\end{array}$ & $\begin{array}{c}\text { Number of } \\
\text { samples with } \\
\text { count }>\mathbf{1 0}^{\mathbf{2}}\end{array}$ & $\begin{array}{c}\text { Number of } \\
\text { samples with } \\
\text { count }>\mathbf{1 0}^{\mathbf{3}}\end{array}$ & $\begin{array}{c}\text { Number of } \\
\text { samples with } \\
\text { count }>\mathbf{1 0}^{\mathbf{4}}\end{array}$ \\
\hline Fish & --- & --- & 7 & 3 \\
\hline Prawn & --- & 3 & 6 & 1 \\
\hline Cuttlefish & 1 & --- & 6 & 3 \\
\hline
\end{tabular}

Table.3 Statistical analytical results of Total Plate Count (TPC) and Total Coliforms Count (TCC) $\mathrm{cfu} / \mathrm{g}$ in the examined samples of Fishes, Prawns and Cuttlefishes

\begin{tabular}{|l|l|c|c|}
\hline \multirow{2}{*}{ Sample Type } & Statistics & $\begin{array}{c}\text { Total Plate Count } \\
\text { (TPC) }\end{array}$ & $\begin{array}{c}\text { Total Coliforms } \\
\text { Count(TCC) }\end{array}$ \\
\hline \multirow{3}{*}{ Fish } & Minimum & $6.70 \times 10^{4}$ & $2.68 \times 10^{3}$ \\
\cline { 2 - 4 } & Maximum & $8.30 \times 10^{5}$ & $1.40 \times 10^{4}$ \\
\cline { 2 - 4 } Prawn & Mean \pm S.D & $2.95 \pm 2.37 \times 10^{5}$ & $7.31 \pm 3.98 \times 10^{3}$ \\
\hline \multirow{3}{*}{ Cuttlefish } & Minimum & $3.50 \times 10^{4}$ & $5.00 \times 10^{2}$ \\
\cline { 2 - 4 } & Maximum & $3.86 \times 10^{7}$ & $1.74 \times 10^{4}$ \\
\cline { 2 - 4 } & Mean \pm S.D & $6.15 \pm 1.22 \times 10^{6}$ & $4.13 \pm 5.19 \times 10^{3}$ \\
\hline & Minimum & $1.00 \times 10^{4}$ & $5.00 \times 10^{1}$ \\
\cline { 2 - 4 } & Maximum & $1.85 \times 10^{6}$ & $2.40 \times 10^{4}$ \\
\cline { 2 - 4 } & Mean \pm S.D & $3.23 \pm 5.50 \times 10^{5}$ & $8.04 \pm 1.01 \times 10^{3}$ \\
\hline
\end{tabular}


Table.4 List of Bacterial species isolated from Fishes, Prawns and Cuttlefishes

\begin{tabular}{|c|c|c|c|c|c|}
\hline FISH SKIN & FISH GILLS & FISH MUSCLES & PRAWN & $\begin{array}{c}\text { CUTTLEFISH } \\
\text { SKIN }\end{array}$ & $\begin{array}{c}\text { CUTTLEFISH } \\
\text { MUSCLES }\end{array}$ \\
\hline $\begin{array}{l}\text { Aeromonas } \\
\text { hydrophila } \\
\text { Klebsiella } \\
\text { pneumoniae } \\
\text { Morganella } \\
\text { morganii } \\
\text { Staphylococcus } \\
\text { lentus } \\
\text { Staphylococcus } \\
\text { sciuri }\end{array}$ & $\begin{array}{l}\text { Vibrio cholerae } \\
\text { Vibrio parahaemolyticus } \\
\text { Aeromonas hydrophila } \\
\text { Pasteurella aerogenes } \\
\text { Shewanella putrifaciens } \\
\text { Staphylococcus } \\
\text { hemolyticus } \\
\text { Staphylococcus warneri } \\
\text { Staphylococcus capitis } \\
\text { Staphylococcus lentus } \\
\text { Ralstonia pickettii }\end{array}$ & $\begin{array}{l}\text { Vibrio alginolyticus } \\
\text { Vibrio } \\
\text { parahaemolyticus } \\
\text { Vibrio fluvialis } \\
\text { Vibrio vulnificus } \\
\text { Aeromonas } \\
\text { hydrophila } \\
\text { Aeromonas } \\
\text { salmonicida } \\
\text { Aeromonas sobria } \\
\text { Morganella morganii } \\
\text { Shewanella } \\
\text { putrifaciens } \\
\text { Staphylococcus } \\
\text { hominis } \\
\text { Staphylococcus sciuri } \\
\text { Staphylococcus } \\
\text { warneri }\end{array}$ & $\begin{array}{l}\text { Vibrio alginolyticus } \\
\text { Vibrio vulnificus } \\
\text { Vibrio parahaemolyticus } \\
\text { Aeromonas hydrophila } \\
\text { Pasteurella aerogenes } \\
\text { Proteus vulgaris } \\
\text { Escherichia coli } \\
\text { Rahnella aquatilis } \\
\text { Morganella morganii } \\
\text { Hafnia alvei } \\
\text { Citrobacter koserii } \\
\text { Staphylococcus hominis } \\
\text { Staphylococcus } \\
\text { saprophyticus } \\
\text { Staphylococcus cohnii }\end{array}$ & $\begin{array}{l}\text { Proteus vulgaris } \\
\text { Citrobacter freundii } \\
\text { Escherichia coli } \\
\text { Morganella morganii } \\
\text { Aeromonas } \\
\text { hydrophila } \\
\text { Aeromonas sobria } \\
\text { Shewanella } \\
\text { putrifaciens } \\
\text { Staphylococcus } \\
\text { aureus } \\
\text { Staphylococcus lentus } \\
\text { Aerococcus viridans }\end{array}$ & $\begin{array}{l}\text { Vibrio alginolyticus } \\
\text { Vibrio } \\
\text { parahaemolyticus } \\
\text { Aeromonas hydrophila } \\
\text { Aeromonas sobria } \\
\text { Providencia stuartii } \\
\text { Morganella morganii } \\
\text { Hafnia alvei } \\
\text { Rahnella aquatilis } \\
\text { Proteus mirabilis } \\
\text { Enterobacter cloacae } \\
\text { Staphylococcus hominis } \\
\text { Staphylococcus aureus } \\
\text { Acinetobacter } \\
\text { baumannii } \\
\text { Psuedomonas luteola }\end{array}$ \\
\hline
\end{tabular}


Table.5 Prevalence of Bacterial species among Fishes, Prawns and Cuttlefishes

\begin{tabular}{|c|c|c|c|c|c|c|c|c|}
\hline \multirow[b]{2}{*}{ S. No } & \multirow[b]{2}{*}{ Bacterial Isolates } & \multicolumn{6}{|c|}{ Name of the Samples } & \multirow{2}{*}{$\begin{array}{c}\text { Total } \\
\text { prevalence }\end{array}$} \\
\hline & & $\begin{array}{l}\text { Fish } \\
\text { Skin } \\
\end{array}$ & $\begin{array}{l}\text { Fish } \\
\text { Gills } \\
\end{array}$ & $\begin{array}{c}\text { Fish } \\
\text { Muscles }\end{array}$ & Prawn & $\begin{array}{c}\text { Cuttlefish } \\
\text { Skin }\end{array}$ & $\begin{array}{c}\text { Cuttlefish } \\
\text { Muscles }\end{array}$ & \\
\hline 01. & Vibrio parahaemolyticus & --- & 1 & 4 & 2 & --- & 5 & 12 \\
\hline 02. & Vibrio alginolyticus & $\begin{array}{c}-- \\
\end{array}$ & $\begin{array}{c}-- \\
\end{array}$ & 2 & 6 & $\begin{array}{c}-- \\
\end{array}$ & 2 & 10 \\
\hline 03. & Vibrio vulnificus & --- & --- & 1 & 2 & --- & --- & 3 \\
\hline 04. & Vibrio cholera & --- & 2 & --- & --- & --- & --- & 2 \\
\hline 05. & Vibrio fluvialis & --- & --- & 1 & --- & --- & --- & 1 \\
\hline 06. & Aeromonas hydrophila & 6 & 8 & 5 & 3 & 2 & 7 & 31 \\
\hline 07. & Aeromonas sobria & --- & --- & 1 & --- & 2 & 5 & 8 \\
\hline 08. & Aeromonas salmonicida & --- & --- & 1 & --- & --- & --- & 1 \\
\hline 09. & Proteus vulgaris & --- & --- & --- & 4 & 1 & --- & 5 \\
\hline 10. & Proteus mirabilis & --- & --- & --- & --- & --- & 1 & 1 \\
\hline 11. & Rahnella aquatilis & --- & --- & --- & 1 & --- & 1 & 2 \\
\hline 12. & Morganella morganii & 1 & --- & --- & 4 & 2 & 1 & 8 \\
\hline 13. & Enterobacter aerogenes & --- & --- & --- & 3 & --- & --- & 3 \\
\hline 14. & Enterobacter cloacae & --- & --- & --- & --- & --- & 1 & 1 \\
\hline 15. & Klebsiella pneumonia & 1 & --- & --- & --- & --- & --- & 1 \\
\hline 16. & Providencia stuartii & --- & --- & --- & --- & --- & 1 & 1 \\
\hline 17. & Hafnia alvei & --- & --- & --- & 1 & --- & 2 & 3 \\
\hline 18. & Escherichia coli & --- & --- & --- & 1 & 1 & --- & 2 \\
\hline 19. & Citrobacter brakii & --- & --- & --- & 2 & --- & --- & 2 \\
\hline 20. & Citrobacter freundii & --- & --- & --- & --- & 1 & --- & 1 \\
\hline 21. & Citrobacter koserii & --- & --- & --- & 1 & $\begin{array}{ll}-- \\
\end{array}$ & $\begin{array}{ll}--- \\
\end{array}$ & 1 \\
\hline 22. & Pasteurella aerogenes & --- & 1 & --- & 4 & --- & --- & 5 \\
\hline 23. & Shewanella putrifaciens & --- & --- & 3 & --- & 1 & 2 & 6 \\
\hline 24. & Staphylococcus hominis & --- & --- & 2 & 2 & --- & 3 & 7 \\
\hline 25. & Staphylococcus lentus & 3 & 1 & $\begin{array}{ll}-- \\
\end{array}$ & $\begin{array}{ll}-- \\
\end{array}$ & 3 & --- & 7 \\
\hline 26. & Staphylococcus aureus & --- & --- & --- & --- & 2 & 3 & 5 \\
\hline 27. & Staphylococcus sciuri & 1 & --- & 2 & --- & --- & --- & 3 \\
\hline 28. & Staphylococcus warneri & --- & 1 & 2 & --- & --- & --- & 3 \\
\hline 29. & Staphylococcus hemolyticus & --- & 2 & --- & --- & --- & --- & 2 \\
\hline 30. & Staphylococcus saprophyticus & --- & --- & --- & 1 & --- & --- & 1 \\
\hline 31. & Staphylococcus cohnii & --- & --- & --- & 1 & --- & --- & 1 \\
\hline 32. & Staphylococcus capitis & --- & 1 & $\begin{array}{c}-- \\
\end{array}$ & $\begin{array}{ll}-- \\
\end{array}$ & $\begin{array}{ll}-- \\
\end{array}$ & --- & 1 \\
\hline 33. & Aerococcus viridians & --- & --- & --- & --- & 5 & --- & 5 \\
\hline 34. & Ralstonia pickettii & --- & 1 & --- & --- & --- & --- & 1 \\
\hline 35. & Acinetobacter baumanii & --- & --- & --- & --- & --- & 1 & 1 \\
\hline 36. & Psuedomonas luteola & --- & --- & --- & --- & --- & 1 & 1 \\
\hline \multicolumn{2}{|c|}{ TOTAL NUMBER OF ISOLATES } & 12 & 18 & 24 & 38 & 20 & 36 & 148 \\
\hline
\end{tabular}


Table.6 The Overall Percentage of Prevalent Bacterial Families among Fishes, Prawns and Cuttlefishes

\begin{tabular}{|c|l|c|c|}
\hline S.No. & \multicolumn{1}{|c|}{ BACTERIAL FAMILY } & $\begin{array}{c}\text { No. \% for } \\
\text { Total 60 Samples }\end{array}$ & $\begin{array}{c}\text { No. \% for } \\
\text { Total 148 } \\
\text { Bacterial Isolates }\end{array}$ \\
\hline 01. & Aeromonadaceae & $40(66.66)$ & 27.02 \\
\hline 02. & Enterobacteriaceae & $31(51.66)$ & 20.94 \\
\hline 03. & Staphylococcaceae & $30(50.00)$ & 20.27 \\
\hline 04. & Vibrionaceae & $28(46.66)$ & 18.91 \\
\hline 05. & Shewanella putrifaciens & $06(10.00)$ & 04.05 \\
\hline 06. & Pasteurella aerogenes & $05(08.33)$ & 03.37 \\
\hline 07. & Aerococcus viridans & $05(08.33)$ & 03.37 \\
\hline 08. & Ralstonia picketii & $01(01.66)$ & 00.67 \\
\hline 09. & Acinetobacter baumanii & $01(01.66)$ & 00.67 \\
\hline 10. & Psuedomonas luteola & $01(01.66)$ & 00.67 \\
\hline
\end{tabular}

Fig.1 Dammam Retail Fish Market

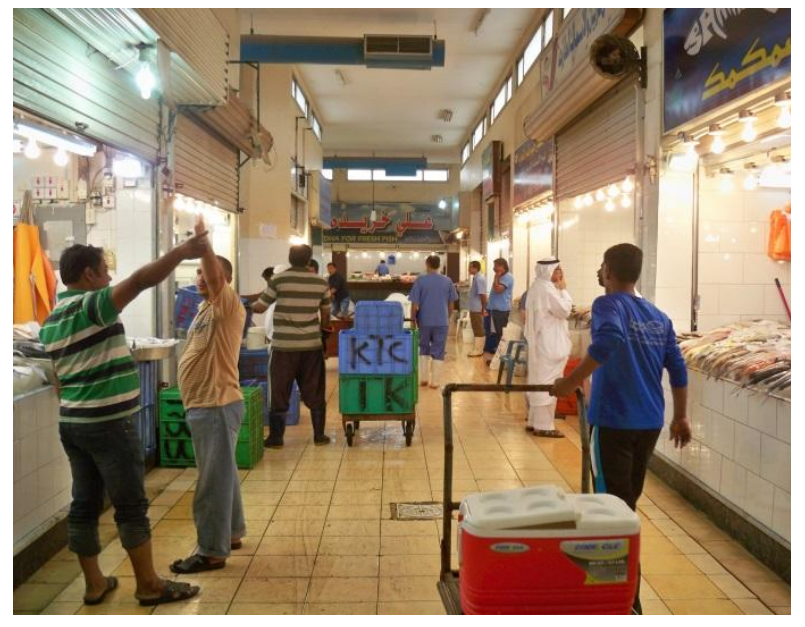

Vibrios are responsible for a number of clinical conditions such as cholera, gastroenteritis, septicaemia and wound infections. Twelve Vibrio species have been documented as potential food-borne disease agents in humans: Vibrio cholerae, Vibrio parahaemolyticus, Vibrio vulnificus, Vibrio alginolyticus, Vibrio furnissi, Vibrio fluvialis, Vibrio damsel, Vibrio mimicus, Vibrio hollisae, Vibrio cincinatiencis, Vibrio harveyi and Vibrio metchnikovii (Shikongo et al., 2012).

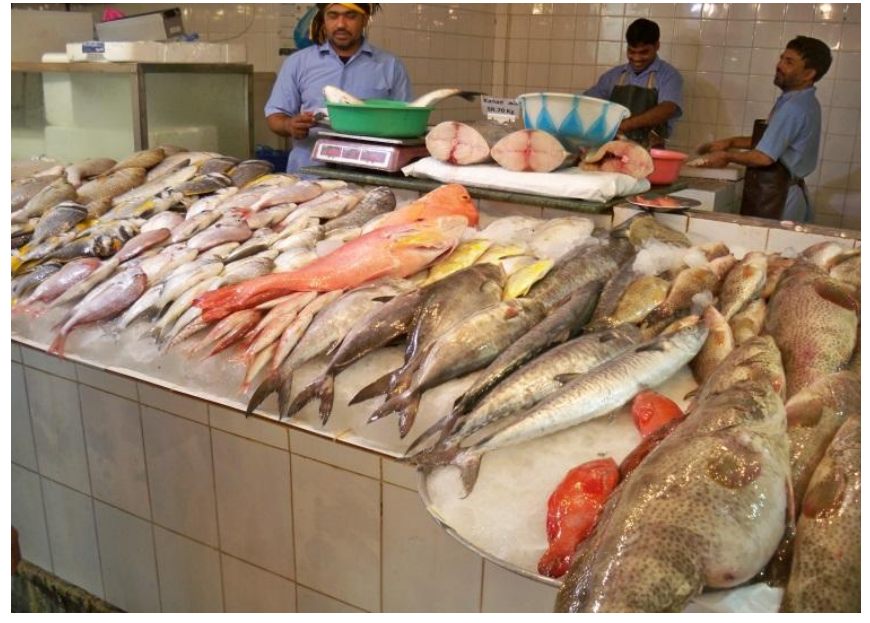

Shewanella putrifaciens were isolated from Fish muscles (3), Cuttlefish Muscles (2) and Cuttlefish Skin (1). The prevalence percentage is around $10 \%$ out of 60 samples analysed.Shewanella putrifaciens can be found in freshwater, brackish and salt water ecosystems. It is a main food spoilage bacterium in marine fish and is known to cause the rotting smell associated with dead fish because of its production of trimethylamine. Infections from Shewanella putrifaciens mainly occurs in soft tissue 
such as Skin, Intra-abdominal areas or in the blood (Pagani, 2003; Mc nair, 2010).

Pasteurella aerogenes is a species usually found in swine and Ralstonia pickettii, Acinetobacter baumannii can be found in moist environments such as soils, rivers and lakes. Psuedomonas luteola can be found in damp environments. All the above organisms can act as Opportunistic pathogens in humans with poor health and people with compromised immune systems.

The findings of this study revealed that the raw seafoods sold at Dammam fish market could be a source of food borne bacterial pathogens. It has also shown that samples of seafoods used in this study were grossly contaminated by pathogenic organisms such as Aeromonas sp, Staphylococci sp, Vibrio $\mathrm{sp}$, Enterobacteriaceae, Shewanella putrifaciens, Pasteurella aerogenes, Aerococcus viridans, Ralstonia pickettii, Acinetobacter baumannii and Psuedomonas luteola. Thus, constitute potential public health hazard due to the unhygienic nature of fish handlers. This call for public health concerns and improvements in handling and processing are needed to minimize the prevalence of the pathogens. The levels of Total Plate Count of bacteria and Total Coliforms Count indicate the urgent need require improving the Quality control and Quality assurance systems of Dammam Fish Market.

\section{Acknowledgements}

Sincere thanks to Municipality officers, workers and vendors of Dammam Fish Market for their kind support during sampling for this study.

\section{References}

Al-Jufaili, M.S. and I.U. Opara. 2006. Status of Fisheries Postharvest in the Sultanate of Oman: Part 1: Handling and marketing system of Fresh fish. $J$. Fisheries Int., 1(2-4): 144-149.

Amira Leila Dib, Nedjoua Lakhdara, Elena Espigares Rodriguez, Rachid Kaboria, Elena Moreno Roldar, Miguel Espigares Garcia, Hafida Koutchoukali, Lindn Guersaichi, Omar Bouaziz, 2014. Prevalence of microbial contamination of Fresh seafood products sold in Constantine, Algeria.

Austin, B., Austin, D.A. 2007. Bacterial Fish Pathogens: Disease of Farmed and Wild fish, $4^{\text {th }}$ ed. Springer-Praxis, London, England.

Bakr, W.M.K., Hazzah, W.A., Abaza, A.F., 2011. Detection of Salmonella and Vibrio species in some seafood in Alexandria. J. AM. Sci., 7: 663-668.

Clucas, I.J. and ward, A.R. 1996. Post Harvest Fisheries Development. A guide to Handling, Preservation, Processing and Quality. Chatham Maritime, Kent ME4TB. United Kingdom. pp. 665.

Cruz-Romero, M., Kelly, A.l., Kerry, J.P. 2008. Influence of packaging strategy on Microbiological and Biochemical changes in high pressure-treated Oysters (Crassostrea gigas). J. Sci. Food Agric., 88(15): 2713-2723.

Das, M.F., Hafiz, M.K. Ahmed and S. Parveen. 2007. Microbiological analysis of some Raw Fish samples, Bangladesh. J. Microbiol., 24(I): 6769.

Elhadi, N., Radu, S., Chen, C.H and Nishibuchi, M. 2004. Prevalence of Potentially Pathogenic Vibrio species in the seafood marketed in Malaysia. J. Food. Prot., 67(7): 1469-1475.

Evelyn Ivana Trindade Damasceno, Lawana Natasha da Gama pantoja, Hamilton Mendes de Figueiredo, Luiza Helena Meller da silva and Antonio Manoel da Cruz Rodrigues, 2015. Microbiota 
of two species of commercially important fish in the Amazon region (Belem-Para-Gayil) Butterfly Peacock Bass (Cichla ocellaris) and Piramutaba (Brachyplatystoma vailantii), African J. Microbiol. Res., Vol 9(9), pp 572-580.

FAO. Corporate Document Repository, Quality aspects associated with Seafood.

Farag, H., EL-S. M. 2006. Incidence of Haemolysin producing Motile Aeromonas in some shell fish and their public health significance in Port-Said City. J. Appl. Sci. Res., 2: 972-979.

Figen cetinkaya, Tulay Elal Mus, Umut celik. 2014. Occurrence of Vibrio, Salmonella and Staphylococcus aureus in retail fresh fish, mussel and shrimp. ACTA VET. BRNO 2014, 83: 73-78.

Francoise. 2010. Occurrence and Role of Lactic acid bacteria in Seafood product. Food. Microbial., 27: 698701.

Fricker, C.R., Tompsett, S., 1989. Aeromonas spp. In foods: a significant cause of food poisoning, Int. J. Food Microbiol., 7: 17-23

Gram, L., Huss H.H. 1996. Microbiological Spoilage of Fish and Fish Products. Int. J. Food Microbiol., 33: 121-137.

Hudson, J.A., Delacy, K.M. 1991. Incidence of motile Aeromonads in New Zealand retail foods. J. Food Prot., 54: 696699.

Huis in't Veld, J.H.J. 1996. Microbial and Biochemical spoilage of foods: An overview. Int. J. Food. Microbiol., 33: 1-18.

Huss, H.H. 1988. Fresh Fish-Quality and Quality Changes. FAO Fisheries series, 29.

Interas. 2003. Isolation, Identification of Bacterial pathogens in Seafish. Govt. Project, pp:22

International Commission of
Microbiological Specifications for Foods. ICMSF. 1986. Microorganisms in Foods 2- Sampling for Microbilogical analysis: Principles \& Specific applications. Toronto, Ontario, Canada, University of Toronto Press ( $2^{\text {nd }}$ Edition).

Karl, H., Schleifer and Wesley, E., Kloos. 1975. Isolation and characterization of Staphylococci from Human skin. I. Amended descriptions of Staphylococcus epidermidis and Staphylococcus saprophyticus and Descriptions of Three New Species: Staphylococcus cohnii, Staphylococcus haemolyticus and Staphylococcus xylosus. Int. J. Systematic Bacteriol., pp. 50-61.

Kawser Ahmed, Abu Hera Muhammad Yousuf, Sabina yeasmin, Nazmul Ahsah, Mujibur Rahman, Monirul Islam. 2008. Prevalence of Microbial load in Shrimp, Penaeus monodon and Prawn, Macrobrachium rosenbergii from Bangladesh. World J. Agri. Sci., 4(3): 852-855.

Kumar, R., Surendran, P.K., Thampuran, W. 2009. Distribution and Genotypic characterization of Salmonella serovars isolated from tropical seafood of Cochin, India. J. Appl. Microbiol., 106: 515-524.

Mahumda, B., Abu, T.A.A., D.M. and P.S. 2010. A comparative microbiological assessment of five types of selected fishes collected from two different markets. Adv. Biol. Res., 4(5): 259165.

Mc nair, Jamilla. 2010. "Shewanella putrifaciens". "Microbe of the week". University of Missouri Biological Department.

Neyts, K., Huys, G., Uyttendaele, M., Swingsm, J. and Debevere, J., 2000. Incidence and Identification of mesophilic Aeromonas spp. From 
retail foods. Lett. Appl. Microbiol., 31(5): 359-363.

Noor, R., Acharjee, M., Ahmed, T., Das, K.K., Paul, L., Munshi, S.K., Urmi, N.J., Rahman, F., and Md. Zahangir Alam. 2013. Microbiological study of Major sea fish available in Local markets of Dhaka City, Bangladesh. $J$. Microbial. Biotechnol. Food Sci., 2(4): 2420-2430.

Okonko, I.O., A.A. Ogunjobi and E.A. Fajobi. 2008. Comparative studies and microbial risk assessment of different Ready-To-Eat (RTE) frozen sea-foods processed in Ijora-Olapa, Lagos state, Nigeria, African J. Biotechnol., 7(16): 2898-2901.

Okonko, I.O., Adebayo-Tayo, B.C., John, M.O., Odu, N.N., Nwanze, J.C., and Ezediokpu, M.N. 2011. Occurrence of potentially pathogenic Vibrio species in seafoods obtained from Oron Creek, 2011. Adv. Biol. Res., 5(6): 356-365.

Pagani, L., Lang, A., Vedovelli, C., et al. Soft tissue infection and bacteremia caused by Shewanella putrifaciens, 2003. J. Clin. Microbiol., Vol 4, 1(5). pp. 2240-1.

Popovic, N.T., Skukan, A.B., Dzidara, P., Coz-Rakovac, R., Strunjak-Perovic, I., Kozacinski, L., Jadan, M., BrlekGorski. 2010. Microbiological Quality of fresh and frozen seafood caught of the ardiatic coast of Croatia. Vet. Med., 55: 233-241.

Rodriguez, A.I., Hariharan, H., Nimrod, S. 2011. Occurrence and Antimicrobial drug resistance of potential bacterial pathogens from Shellfish, including Queen Conchs (Strombus gigas) and Whelks (Cittarum pica) in Grenada, Web Med. Central Microbiol., 2: WMC001943.

SASO 1571 (GS 1361) Chilled Shrimps. SASO 708 (GS 380) Chilled Fish.

SASO. 1556 (GS 1016) Microbiological
Criteria for Foodstuffs-Part 1

Shabarinath, S., Kumar, H.S., Khushiramani, R., Karunasagar, I. 2007. Detection and Characterization of Salmonella associated with Tropical seafood. Int. J. Food Microbiol., 114: 227-233.

Shewan, J.M. 2000. The Microbiology of sea water fish. In Fish as Food. Ed by G. Borgstrom, 1. New York Academic Press., pp:487.

Shikongo-Nambabi, M.N.N.N., Petrus, N.P and M.B. Schneides. 2012. The role, Isolation and Identification of Vibrio species on the Quality and Safety of Seafood. Biotechnol. Mol. Biol. Review, Vol. 7(2), pp. 16-30.

Tsai, G.J., Chen, T.W. 1996. Incidence and toxigenicity of Aeromonas hydrophila in seafood. Intl. J. Food Microbiol., 31: 121-131.

USFDA BAM (Online), http://www.fda.gov/Food/FoodScience Research/LaboratoryMethods/ucm200 6949.htm

Van den Broek, M.J.M., Mossel, D.A.A., Mol, H. 1984. Microbiological Quality of retail fresh fillets in the Netherlands, Int. J. Food Microbiol., 1: 3-61.

Vivekanandan, G., Hatha., A.A.M., Lakshmanaperumal samy, P. 2005. Prevalence of Aeromonas hydrophila in fish and prawns from the seafood market of Coimbatore, South India. Food Microbiol., 22: 131-137.

Wesley, E., kloos and Karl, H., Schleifer, Isolation and characterization of Staphylococci from Human skin, 1975. II. Descriptions of Four New Species: Staphylococcus warneri, Staphylococcus capitis, Staphylococcus hominis and Staphylococcus simulans. Int. J. Systematic Bacteriol., pp. 62-79.

Yagoub, S.O., Ahmed, T.M. 2004. 
Pathogenic microorganisms in freshwater samples collected from Khartoum Central Market, Sudan. J. Vet. Sci. Anim. Husbandry, 43(1-2): 32-37.
Young, Uh., Jeong, S.S., In, H.J., Kap, J.Y., Soon, K.H. 2002. Penicillin-resistant Aerococcus viridans Bacteremia Associated with Granulocytopenia, $J$. Korean Med. Sci., 17: 113-5.

\section{How to cite this article:}

Sami Shabeeb Al Shabeeb, M.A. Mohamed Ibrahim and Ghamri H. Al Ramadhan. 2016. A Comparative Microbial Quality Assessment among Fishes, Prawns and Cuttlefishes collected from Dammam Fish Market. Int.J.Curr.Microbiol.App.Sci. 5(9): 405-418. doi: http://dx.doi.org/10.20546/ijcmas.2016.509.044 